\title{
THE EFFECT OF EXPOSURE ROUTE ON THE DISTRIBUTION AND EXCRETION OF HEXACHLORONAPHTHALENE IN RATS
}

\author{
ANNA KILANOWICZ, ADAM DARAGÓ, and MAŁGORZATA SKRZYPIŃSKA-GAWRYSIAK
}

\author{
Medical University, Łódź, Poland \\ Department of Toxicology, Faculty of Pharmacy
}

\begin{abstract}
Objectives: Polychlorinated naphthalenes (PCNs), like other persistent organic pollutants (POPs), are widespread, global environmental contaminants. These compounds still represent a great environmental problem, mostly because of the risk of secondary air pollution. They are characterized by long durability and tendency to bioaccumulate, which means that they are practically ubiquitous in all environmental media and ecosystems. The aim of this study was to investigate the distribution and excretion of hexachloronaphthalene $(\mathrm{HxCN})$ in rats following a single intraperitoneal or intragastrical administration. Materials and Methods: Experiments were performed on male outbred Wistar rats with body weight of 220-240 g. They were given $\left[{ }^{14} \mathrm{C}\right]-\mathrm{HxCN}$ intraperitoneally (i.p.) or intragastrically (p.o.) in a single dose of $0.3 \mathrm{mg}(150 \mathrm{kBq})$ per rat. The distribution of radioactivity in blood and selected organs or tissues, as well as urine and faeces excretion were traced following the administration. Results: The decline of $\left[{ }^{14} \mathrm{C}\right]-\mathrm{HxCN}$ in plasma was biphasic and the calculated half-lives for phases I and II were $\sim 6$ and $350 \mathrm{~h}$, respectively. Following $120 \mathrm{~h}$ after administration, $\sim 51 \%$ (intragastrical) and $\sim 34 \%$ (intraperitoneal) of the dose were excreted with faeces. Regardless of the administration route, the highest HxCN concentrations were found in liver and adipose tissue, where the compound showed high retention: the highest retention in liver was found $24 \mathrm{~h}$ after intragastrical (32\%) and intraperitoneal (38\%) administration while in adipose tissue $\sim 30 \%$ retention was observed $120 \mathrm{~h}$ after $\mathrm{HxCN}$ administration regardless of its route. Conclusions: Following the calculation of the balance of total $\left[{ }^{14} \mathrm{C}\right]-\mathrm{HxCN}$ excreted and stored, it was found that hexachloronaphthalene belongs to the compounds of a slow turnover rate, and in the case of repeated exposure it may accumulate in the rat body.
\end{abstract}

Key words:

Hexachloronaphthalene, Distribution, Excretion, Rat

\section{INTRODUCTION}

Polychlorinated naphthalenes (PCNs) comprise a group of compounds, consisting of naphthalene substituted with 1-8 chlorine atoms, yielding 75 possible congeners [1]. They were previously used for a variety of industrial purposes owing to their dielectric, water-repellent, flame-retardant, and anti-fungal properties [1]. PCNs have also been found in polychlorinated biphenyl (PCB) formulations [2] and combustion-related emissions, such as those of waste incinerators [3,4]. Mixtures of PCNs have been produced in several countries under the trade names Halowax, Nibren and Seekay waxes [1,3,5]. Production figures for PCNs are not well known, but have been estimated to be about $10 \%$ of the global PCB production [5]. Despite the fact that the manufacture of PCNs was finally stopped in the 1980s, they are still present in

The study was in part financially supported by the National Science Centre (Grant No. NN 40427 1240).

Received: November 25, 2011. Accepted: January 16, 2012.

Address reprint request to: A. Kilanowicz, Department of Toxicology, Faculty of Pharmacy, Medical University, Muszyńskiego 1, 90-151 Łódź, Poland

(e-mail: anna.kilanowicz@umed.lodz.pl). 
the environment due to their persistent, lipophilic properties [6]. It is estimated that 1.0 tons of PCNs were emitted in Europe in 2000, as a result of waste and other combustions, industrial sources, solvent and product usage [5].

Polychlorinated naphthalenes, like other persistent organic pollutants (POPs), are widespread global environmental contaminants and they still represent a great environmental problem, mostly because of the risk of secondary air pollution [4,5,7-9]. They are characterized by long durability and tendency to bioaccumulate, which means that they are practically ubiquitous in all environmental media and ecosystems [3,10-14]. These pollutants have been detected in air, water, sediments, soils and biota [15-17].

Food contamination is one of the most serious consequences of the natural environmental contamination by PCNs. Consumption of contaminated food is the major source of human exposure to PCNs [18]. The studies carried out by different researchers show that PCNs, especially hexachloronaphthalene $(\mathrm{HxCN})$, have been found in food of animal origin (primarily in fish, but also in milk, meat and eggs) $[6,12,14,17,19-21]$. Foods that were subject to some measure of processing (oils, cereals, meat etc.) and fish showed highest levels of PCNs [22,23].

Thus, it is not surprising that PCNs have been found in humans and wildlife. General population studies carried out in different regions of the globe have revealed the highest concentrations of PCNs (mostly pentaand hexachloronaphthalene isomers) in liver and adipose tissue $[1,4,24,25]$. The Swedish studies performed in 1972-1992 revealed the presence of these compounds (including mainly $1,2,3,5,6,7-\mathrm{HxCN}$ ) in breast milk, which may be particularly dangerous to the developing infants [26], mostly because the elimination of compounds like PCNs and their lipophilic metabolites from body fat is very slow [1].

The literature review shows that data on the disposition of single PCN congeners in the rat body, including a comprehensive assessment of their absorption, distribution and excretion are rather scarce. The majority of the reported experiments have been performed for the commercially available mixtures of PCNs [1]. Considering that individual congeners of the discussed compounds may significantly differ in their distribution and affinity to the critical organs in general and liver in particular, the toxicokinetics of hexachloronaphthalene, one of the most toxic [27-29] and the most intensely bioaccumulative $[14,30]$ congeners, was investigated in this study.

The aim of this study was to investigate the distribution and excretion of hexachloronaphthalene in rats following a single intraperitoneal or intragastrical administration.

\section{MATERIALS AND METHODS}

\section{Chemicals}

${ }^{14} \mathrm{C}$-labelled hexachloronaphthalene $\left[{ }^{14} \mathrm{C}\right]-\mathrm{HxCN}$ with a specific activity of $500 \mathrm{MBq} / \mathrm{g}$ was obtained from the Institute of Radiation, Faculty of Chemistry, Technical University of Łódź, Poland as a mixture of isomers $\left[{ }^{14} \mathrm{C}\right]-\mathrm{HxCN}$ (over 94\%) and it contained mainly $\left[{ }^{14} \mathrm{C}\right]-1,2,3,5,6,7-$ $\mathrm{HxCN}(81 \%)$. $\left[{ }^{14} \mathrm{C}\right]-\mathrm{HxCN}$ was synthesized by dechlorination of $\left[{ }^{14} \mathrm{C}\right]$-octaCN [31]. Other chemicals used were of the highest grade commercially available.

\section{Animals}

Adult male Wistar rats (aged eight weeks) weighing 220-240 g from the breeding colony of the Medical University, Łódź, were used in the experiments.

The animals were supplied at least one week before the experiment and were fed a standard pelletized diet (Murigram from Agropol, Motycz, Poland) and had free access to water. The exposed rats were housed five per cage (cage size, $35 \times 55 \times 25 \mathrm{~cm}$ ) at a room temperature of $21-23^{\circ} \mathrm{C}$, and relative humidity of $55 \pm 5 \%$. The animals were maintained in a constant light/dark cycle of 12/12 h. 


\section{Animal treatment}

$\left[{ }^{14} \mathrm{C}\right]-\mathrm{HxCN}$ was dissolved in sunflower oil and administered to the male rats ( 5 animals/group were used per one time point) intraperitoneally (i.p.) or intragastrically (p.o.) via a metal gastric tube in a single dose of $1.3 \mathrm{mg} / \mathrm{kg}$ body weight (b.w.) and about $0.3 \mathrm{mg}(150 \mathrm{kBq})$ per animal in a volume of $0.5 \mathrm{ml} / \mathrm{rat}$. After the exposure to $\left[{ }^{14} \mathrm{C}\right]-\mathrm{HxCN}$, the animals were housed in individual metabolic cages (Simax, the former Czechoslovakia) and kept for five days $(120 \mathrm{~h})$ to enable separate collection of urine and faeces. In accordance with OECD guidelines, body mass of the animals, as well as fodder and water consumption were controlled every day.

\section{Sampling of biological material and measurements of radioactivity}

Blood samples were collected from the tail veins of eight rats using calibrated, heparinized capillaries following only a single intraperitoneal administration of the compound; $0.03 \mathrm{ml}$ of blood was collected each time (1-432 h). The kinetics of $\left[{ }^{14} \mathrm{C}\right]-\mathrm{HxCN}$ activity in plasma was determined using the Jandel Co. SIGMA PLOT 3.0 for WINDOWS software.

Rats were decapitated at appropriate time intervals and the tissues were removed for the determination of radioactivity. Tissue water homogenates (20\%), faeces water homogenates $(10 \%)$ and blood were digested according to the method of Mahin and Lofberg [32].

Body composition estimates for blood and muscle were 7\% and $40 \%$ [33,34], and $12 \%$ for adipose tissue [35]. Urine samples, diluted with water to $25 \mathrm{ml}$, and plasma samples were measured directly. All radioactivity measurements were carried out using a Racbeta 1209 (LKB, Sweden), liquid scintillation counter and EcoLume ${ }^{\mathrm{TM}}$ from MP Biomedicals, LLC (USA) as the scintillation mixture. Counting correction was achieved using the external standard method.

\section{ETHICS}

All experimental procedures were carried out according to the Directive of the European Parliament and of the Council (2010/63/UE) on the protection of animals used for scientific purposes. The investigations were performed with the permission of the Local Ethical Committee for Experimentation on Animals of Łódź, Poland (No 42/LB 478/2009).

\section{RESULTS}

\section{Intraperitoneal administration}

The decline in plasma

The kinetics of radioactivity declined in blood plasma within $1-432 \mathrm{~h}$ after a single i.p. administration of $\left[{ }^{14} \mathrm{C}\right]-$ $\mathrm{HxCN}$; it was expressed by the following equation: $\mathrm{A}=0.24 \mathrm{e}^{-0.119 t}+0.08 \mathrm{e}^{-0.002 t}$; which means that the decline of $\left[{ }^{14} \mathrm{C}\right]-\mathrm{HxCN}$ in plasma was biphasic and the calculated half-lives for phases I and II were about 6 and $350 \mathrm{~h}$, respectively.

The excretion

The results of $\left[{ }^{14} \mathrm{C}\right]-\mathrm{HxCN}$ excretion within $24-120 \mathrm{~h}$, following a single i.p. administration at a dose of $0.3 \mathrm{mg} / \mathrm{rat}$ $(150 \mathrm{kBq} /$ animal) are summarized in Table 1.

After i.p. administration of the compound, its excretion via faeces (the main excretion route) was slow; in total, $34 \%$ of the received $\mathrm{HxCN}$ dose were excreted after five days. A 24-h excretion of $\mathrm{HxCN}$ in faeces during five days of sampling was comparable, about $6 \%$ of the received dose/day $(6.57 \pm 1.62)$. Urinary excretion of $\mathrm{HxCN}$ was marginal, its total value after five days was about $1 \%$ of the received dose.

\section{Tissue distribution}

The tissue and distribution of $\left[{ }^{14} \mathrm{C}\right]-\mathrm{HxCN}$ radioactivity in the individual organs and tissues, expressed in terms 
Table 1. Excretion of $\left[{ }^{14} \mathrm{C}\right]-\mathrm{HxCN}$-derived radioactivity in urine and faeces, expressed as percentage of total dose after a single intraperitoneal administration of $0.3 \mathrm{mg}\left[{ }^{14} \mathrm{C}\right]-\mathrm{HxCN}$ per rat $(150 \mathrm{kBq} / \mathrm{rat})^{*}$

\begin{tabular}{|c|c|c|c|c|c|}
\hline \multirow[t]{2}{*}{ Medium } & \multicolumn{5}{|c|}{$\begin{array}{l}\text { Time following the administration } \\
\text { (h) }\end{array}$} \\
\hline & $0-24$ & $24-48$ & $48-72$ & $72-120$ & $0-120$ \\
\hline Urine & $0.33 \pm 0.04$ & $0.22 \pm 0.05$ & $0.10 \pm 0.05$ & $0.30 \pm 0.12$ & $0.95 \pm 0.07$ \\
\hline Faeces & $5.03 \pm 0.93$ & $8.25 \pm 0.74$ & $6.42 \pm 0.79$ & $14.09 \pm 0.98$ & $33.79 \pm 1.81$ \\
\hline Total & $5.36 \pm 0.89$ & $8.47 \pm 0.65$ & $6.52 \pm 0.82$ & $14.39 \pm 1.05$ & $34.74 \pm 0.94$ \\
\hline
\end{tabular}

* The values are presented as mean $\pm \mathrm{SD}$ for five rats.

of $\mathrm{kBq} / \mathrm{g}$ tissue within 24-504 $\mathrm{h}$ after the single i.p. administration is shown in Figure 1.

Referring now to Figure 1, the highest $\left[{ }^{14} \mathrm{C}\right]-\mathrm{HxCN}$ concentrations were found in the liver and in the adipose tissue. Liver HxCN concentration was by several times higher than that in the abdominal adipose tissue. Liver/Adipose (L/A) concentration ratio values were: 3.6 after $24 \mathrm{~h}$; 3.0 after $48 \mathrm{~h} ; 2.5$ after $72 \mathrm{~h} ; 1.7$ after $120 \mathrm{~h}$; and 1.4 after $504 \mathrm{~h}$. In the remaining tissues and organs, $\left[{ }^{14} \mathrm{C}\right]-\mathrm{HxCN}$ concentration values measured within 24-504 h after administration were at least 10 times lower compared with the corresponding values for the liver and adipose tissues. The maximum value of $\left[{ }^{14} \mathrm{C}\right]-\mathrm{HxCN}$ radioactivity in liver, spleen, blood and muscles was observed $24 \mathrm{~h}$, and in other organs $120 \mathrm{~h}$ after $\mathrm{HxCN}$ administration. At the final time point (504 h after administration) $\left[{ }^{14} \mathrm{C}\right]-\mathrm{HxCN}$ concentrations were significantly decreased in the majority of tissues
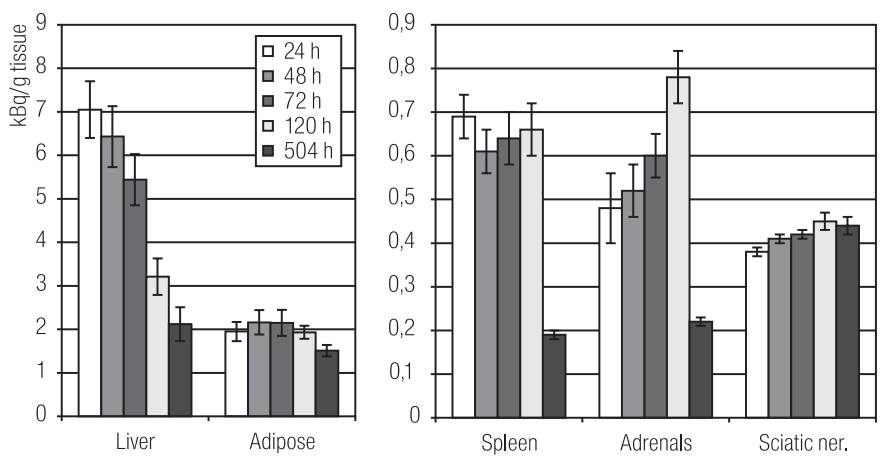

Each point represents the mean \pm SD of five animals.

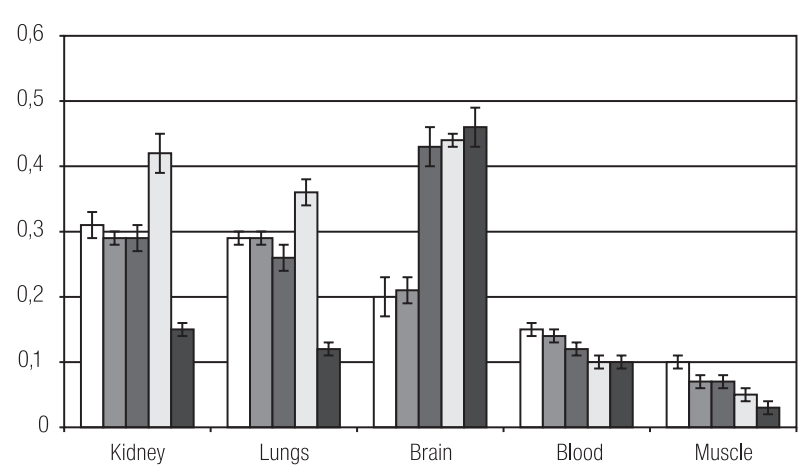

and organs tested, except for brain, sciatic nerve and blood. In brain and sciatic nerve no downward trend in $\mathrm{HxCN}$ levels were observed even $504 \mathrm{~h}$ after the administration.

Total balance of $\left[{ }^{14} \mathrm{C}\right]-\mathrm{HxCN}$ deposited in the tested organs (tissues) and excreted from the body within 24-120 h following a single i.p. administration is presented in Table 2. Liver and adipose tissue played a major role in the balance of $\left[{ }^{14} \mathrm{C}\right]-\mathrm{HxCN}$ deposited in the body (about $38 \%$ and $35 \%$ of the received dose, respectively) from the first day after the compound administration. Within first three days, about $75 \%$ of the administrated dose were accumulated in all tested organs and tissues. Five days (120 h) after $\mathrm{HxCN}$ administration, the body retention was still very high, over $58 \%$; however, the compound deposits in the liver were already significantly lower (by over 50\% compared with those after $24 \mathrm{~h}$ ). No similar effect could be observed in adipose tissue, where the level of the deposited compound was maintained at the

Fig. 1. Specific radioactivity of $\left[{ }^{14} \mathrm{C}\right]-\mathrm{HxCN}$ in the tissue after a single intraperitoneal administration $\left[{ }^{14} \mathrm{C}\right]-\mathrm{HxCN}$ of $0.3 \mathrm{mg}(150 \mathrm{kBq}) / \mathrm{rat}$ 
Table 2. Total balance of $\left[{ }^{14} \mathrm{C}\right]-\mathrm{HxCN}$-derived radioactivity expressed as percentage of total dose after a single intraperitoneal administration of $0.3 \mathrm{mg}\left[{ }^{14} \mathrm{C}\right]-\mathrm{HxCN}$ per rat $(150 \mathrm{kBq} / \mathrm{rat})^{*}$

\begin{tabular}{lccccc}
\hline \multirow{2}{*}{ Medium } & \multicolumn{5}{c}{ Time following the administration } \\
& 24 & 48 & 72 & 120 & 504 \\
\cline { 2 - 5 } & $37.58 \pm 4.04$ & $34.27 \pm 3.05$ & $29.07 \pm 3.49$ & $17.74 \pm 4.49$ & $13.30 \pm 2.47$ \\
\hline Liver & $34.37 \pm 5.68$ & $39.75 \pm 5.08$ & $39.25 \pm 5.43$ & $34.68 \pm 3.94$ & $28.99 \pm 2.50$ \\
Adipose tissue & & & & & \\
$\quad$ abdominal) & $5.09 \pm 1.04$ & $4.21 \pm 1.12$ & $4.30 \pm 0.95$ & $3.91 \pm 0.88$ & $1.92 \pm 0.64$ \\
Muscles & $1.64 \pm 0.28$ & $1.49 \pm 0.18$ & $1.32 \pm 0.10$ & $1.30 \pm 0.10$ & $1.12 \pm 0.11$ \\
Blood & 0.59 & 0.52 & 0.54 & 0.47 & 0.28 \\
Remaining tissues & 79.27 & 80.24 & 74.48 & 58.10 & 45.74 \\
Total in tissues & $0-24$ & $0-48$ & $0-72$ & $0-120$ & not determined \\
Excretion (h) & $0.33 \pm 0.04$ & $0.55 \pm 0.05$ & $0.65 \pm 0.06$ & $0.95 \pm 0.07$ & \\
$\quad$ urine & $5.03 \pm 0.93$ & $13.28 \pm 1.23$ & $19.70 \pm 1.30$ & $33.79 \pm 1.81$ & \\
$\quad$ faeces & 84.63 & 93.55 & 94.29 & 92.37 & \\
Total balance & & & & & \\
\hline
\end{tabular}

* The values are presented as mean \pm SD for five rats.

same level (over 35\%). In total, 21 days (504 h) after administration, body retention of $\left[{ }^{14} \mathrm{C}\right]-\mathrm{HxCN}$ was about $46 \%$, of which $\sim 13 \%$ were found in liver and $\sim 29 \%$ in adipose tissue. The total balance of $\mathrm{HxCN}$ deposited in organs and excreted from the body after five days was about $93 \%$ of the administered dose, of which about $35 \%$ were excreted.

\section{Oral administration}

The excretion

The results of $\left[{ }^{14} \mathrm{C}\right]-\mathrm{HxCN}$ excretion within $24-120 \mathrm{~h}$ following a single p.o. administration at a dose of $0.3 \mathrm{mg} / \mathrm{rat}$ $(150 \mathrm{kBq} /$ animal $)$ are summarized in Table 3.
After p.o. administration, faeces were the main route of $\mathrm{HxCN}$ elimination and, following five days, over $51 \%$ of the administered dose were excreted. The first $24 \mathrm{~h}$ were the most important for the balance of $\mathrm{HxCN}$ elimination (about $34 \%$ of the total dose).

Like after i.p. administration, $\mathrm{HxCN}$ excretion in urine was of marginal significance; less than $1 \%$ of the total dose was excreted via this route after five days.

Tissue distribution

Figure 2 shows the distribution of $\left[{ }^{14} \mathrm{C}\right]-\mathrm{HxCN}$ radioactivity in selected tissues and organs, in terms of $\mathrm{kBq} / \mathrm{g}$ tissue,

Table 3. Excretion of $\left[{ }^{14} \mathrm{C}\right]-\mathrm{HxCN}$-derived radioactivity in urine and faeces, expressed as percentage of total dose after a single intragastrical administration of $0.3 \mathrm{mg}\left[{ }^{14} \mathrm{C}\right]-\mathrm{HxCN}$ per rat $(150 \mathrm{kBq} / \mathrm{rat}) *$

\begin{tabular}{lccccc}
\hline \multirow{2}{*}{ Medium } & \multicolumn{5}{c}{ Time following the administration } \\
& \multicolumn{5}{c}{$(\mathrm{h})$} \\
\cline { 2 - 6 } & $0-24$ & $24-48$ & $48-72$ & $72-120$ & $0-120$ \\
\hline Urine & $0.18 \pm 0.03$ & $0.12 \pm 0.02$ & $0.10 \pm 0.05$ & $0.22 \pm 0.09$ & $0.62 \pm 0.06$ \\
Faeces & $34.02 \pm 1.53$ & $9.25 \pm 2.34$ & $3.45 \pm 0.89$ & $4.49 \pm 1.05$ & $51.21 \pm 4.51$ \\
Total & $34.20 \pm 0.39$ & $9.37 \pm 2.48$ & $3.55 \pm 1.02$ & $4.71 \pm 0.55$ & $51.83 \pm 4.24$ \\
\hline
\end{tabular}

* The values are presented as means \pm SD for five rats. 

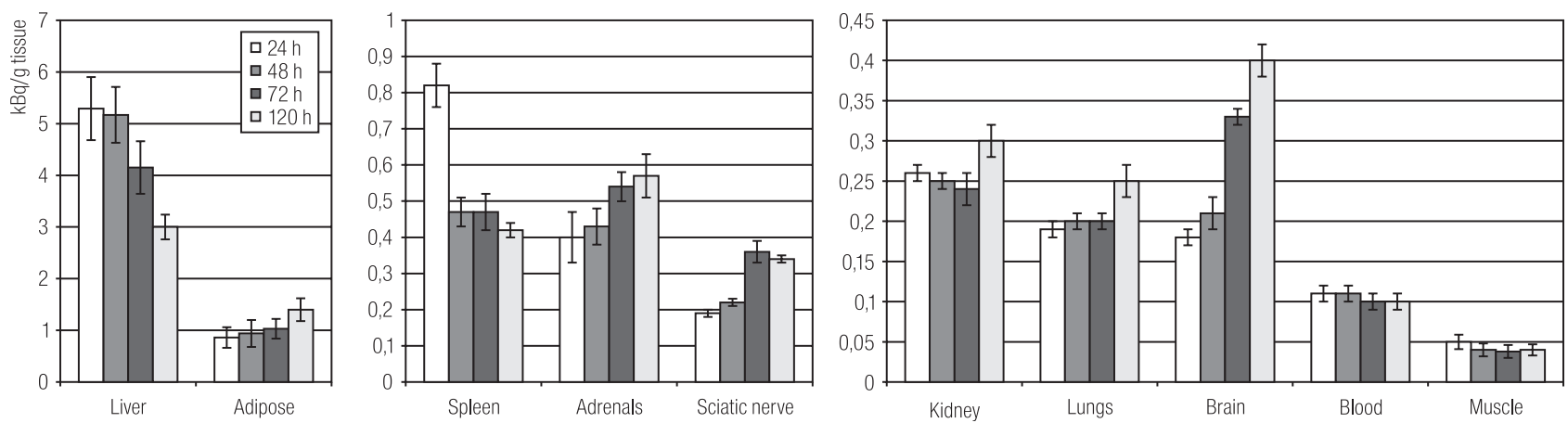

Each point represents the mean $\pm \mathrm{SD}$ of five animals.

Fig. 2. Specific radioactivity of $\left[{ }^{14} \mathrm{C}\right]-\mathrm{HxCN}$ in the tissue after a single intragastrical administration $\left[{ }^{14} \mathrm{C}\right]-\mathrm{HxCN}$ of $0.3 \mathrm{mg}(150 \mathrm{kBq}) / \mathrm{rat}$

within 24-120 $\mathrm{h}$ after a single p.o. administration. Like after i.p. administration, the highest $\left[{ }^{14} \mathrm{C}\right]-\mathrm{HxCN}$ concentrations were observed in liver and in adipose tissue. $\mathrm{HxCN}$ concentration was several times higher in the liver than in the abdominal adipose tissue and the calculated $\mathrm{L} / \mathrm{A}$ ratio was 6.22 after $24 \mathrm{~h}, 5.5$ after $48 \mathrm{~h}, 3.9$ after $72 \mathrm{~h}$ and 2.1 after $120 \mathrm{~h}$.

Maximum $\left[{ }^{14} \mathrm{C}\right]-\mathrm{HxCN}$ radioactivity in liver and spleen was found already $24 \mathrm{~h}$ after its administration. In other tissues and organs, the highest concentrations of the compound were observed $120 \mathrm{~h}$ after administration. In liver and spleen, unlike in other organs, $\mathrm{HxCN}$ concentrations significantly decreased (about 50\%) after $120 \mathrm{~h}$ as compared with the maximum level after $24 \mathrm{~h}$.

Total balance of $\left[{ }^{14} \mathrm{C}\right]-\mathrm{HxCN}$ deposited in the tested organs (tissues) and eliminated from the body within 24-120 h, following a single p.o. administration, is shown in Table 4.

Table 4. Total balance of $\left[{ }^{14} \mathrm{C}\right]-\mathrm{HxCN}$-derived radioactivity expressed as percentage of total dose after a single intragastrical administration of $0.3 \mathrm{mg}\left[{ }^{14} \mathrm{C}\right]-\mathrm{HxCN}$ per rat $(150 \mathrm{kBq} / \mathrm{rat})^{*}$

\begin{tabular}{|c|c|c|c|c|}
\hline \multirow[t]{2}{*}{ Medium } & \multicolumn{4}{|c|}{$\begin{array}{l}\text { Time following the administration } \\
\text { (h) }\end{array}$} \\
\hline & 24 & 48 & 72 & 120 \\
\hline Liver & $31.74 \pm 5.18$ & $27.60 \pm 4.35$ & $23.57 \pm 3.39$ & $16.04 \pm 3.00$ \\
\hline $\begin{array}{r}\text { Adipose tissue } \\
\text { (abdominal) }\end{array}$ & $16.17 \pm 4.08$ & $16.98 \pm 5.58$ & $19.20 \pm 3.83$ & $26.10 \pm 4.54$ \\
\hline Muscles & $3.15 \pm 0.84$ & $2.46 \pm 0.90$ & $2.31 \pm 0.65$ & $2.60 \pm 0.58$ \\
\hline Blood & $1.34 \pm 0.09$ & $1.20 \pm 0.10$ & $0.90 \pm 0.07$ & $0.95 \pm 0.08$ \\
\hline Remaining tissues & 0.40 & 0.37 & 0.38 & 0.36 \\
\hline Total in tissues & 52.80 & 48.61 & 46.36 & 46.05 \\
\hline Excretion (h) & $0-24$ & $0-48$ & $0-72$ & $0-120$ \\
\hline urine & $0.18 \pm 0.03$ & $0.30 \pm 0.03$ & $0.40 \pm 0.05$ & $0.62 \pm 0.06$ \\
\hline faeces & $34.02 \pm 1.53$ & $43.25 \pm 3.83$ & $46.72 \pm 4.24$ & $51.21 \pm 4.51$ \\
\hline Total balance & 87.00 & 91.16 & 93.48 & 97.88 \\
\hline
\end{tabular}

* The values are presented as mean \pm SD for five rats. 
Like in i.p. administration, liver and adipose tissue proved to be the most essential for the balance of $\left[{ }^{14} \mathrm{C}\right]-\mathrm{HxCN}$ deposited in the body. Almost $32 \%$ of total dose was accumulated in the liver after $24 \mathrm{~h}$. Five days after administration, the level of $\mathrm{HxCN}$ deposited in this organ was $16 \%$, a value similar to that observed after i.p. administration. After the same period of time $\left[{ }^{14} \mathrm{C}\right]-\mathrm{HxCN}$ body retention was over $46 \%$ of the total dose, of which about $26 \%$ of the compound was deposited in adipose tissue. Total balance of $\left[{ }^{14} \mathrm{C}\right]-\mathrm{HxCN}$ retained and excreted from the rat body $120 \mathrm{~h}$ after administration was almost $98 \%$, of which about $52 \%$ were excreted.

Quantitative calculations of $\left[{ }^{14} \mathrm{C}\right]-\mathrm{HxCN}$ deposited in tissues after both i.p. and p.o. administrations should be regarded as approximate values due to the fact that they may be encumbered with an error resulting from the adopted theoretical assumptions about the proportion of the muscular and fatty tissues relative to the total body mass of the rat. $\left[{ }^{14} \mathrm{C}\right]-\mathrm{HxCN}$ radioactivity was measured in selected tissues and organs, and thus it was not measured in the alimentary tract and its contents, skin, bones or tendons.

\section{DISCUSSION}

Polychlorinated naphthalenes have been detected in human adipose tissue samples [1,24,36,37], liver [24], blood [38,39] and breast milk [26,40,41] of the general population.

The PCN congener/isomer pattern found in human samples was significantly different from that in the commercial PCN mixtures [1]. The dominating congeners in almost all human specimens examined were two penta- and two hexa- isomers, namely 1,2,3,5,7/1,2,4,6,7-pentachloronaphthalene and 1,2,3,4,6,7/1,2,3,5,6,7-hexachloronaphthalene $[24,26,30,36,37,39]$.

Toxicological symptoms induced by PCNs are very similar to those caused by polychlorodibenzodioxins (PCDDs) [27,28]. The studies performed on rats by
Kilanowicz et al. [29,42,43] apparently confirm this observation. They show that PCNs, like dioxins, are very strong inducers of CYP1 A in liver [29,42,44]. They also induce anorectic effect leading to cachexy [29,42,44], promote teratogenicity (cleft palate and hydronephrosis) and are fetotoxic in the absence of maternal toxicity [43]. The similarity in the toxic effect between PCNs and TCDD has also been reported by Omura et al. [45]. They have provided evidence that gestational administration of 1,2,3,4,6,7-hexachloronaphthalene already in a very low dose $(1 \mu \mathrm{g} / \mathrm{kg}$ b.w. $)$ to pregnant rats has been found to accelerate the onset of spermatogenesis in male offspring.

Bearing in mind that toxic effects the compound exerts on the body depend not only on its concentration (dose) but also on the time of its action, the analysis of toxicokinetics may prove to be essential for the elucidation of the mechanism by which the toxic effect is exerted. It is also important to find out which PCN congener is most bioaccumulative and which organ can be regarded as critical.

Although experimental data are limited, the toxicokinetics of PCNs resembles that of related polyhalogenated aromatic compounds e.g., TCDD, which can be absorbed via oral, dermal, and inhalation routes. As with these classes of substances, the lower chlorinated naphthalenes are less persistent in the body than the more highly chlorinated ones.

The literature review shows that the majority of comparative studies on kinetics, including elimination and distribution, have been performed for PCN technical mixtures [30,46,47]. But there are only a few studies concerning tissue distribution and elimination of selected polychlorinated naphthalenes, e.g. tetra- and pentachloronaphthalene [48]. Only one examination was performed for hexachloronaphthalene retention in liver and adipose tissue; however, its distribution in other organs or its excretion was not investigated [30].

In view of the fact that hexachloronaphthalene is regarded not only as the most bioaccumulative [30] but also as probably 
the most toxic amongst all PCNs [1], this work presents data on the tissue distribution and excretion of $\left[{ }^{14} \mathrm{C}\right]-\mathrm{HxCN}$ in rats. To compare and comprehensively assess absorption, distribution and excretion, the rats were administered $\left[{ }^{14} \mathrm{C}\right]$ $\mathrm{HxCN}$ via two routes: intraperitoneal and intragastric.

Our experiment provides firm evidence that hexachloronaphthalene, regardless of the administration route, intensively accumulates not only in adipose tissue, but also in liver, which makes it different from other PCN congeners, such as e.g. tetra- or pentachloronaphthalene [48]. The data calculated from kinetic equation indicating $\mathrm{HxCN}$ decline in plasma after its single intraperitoneal administration points to a possible accumulation of $\mathrm{HxCN}$ and presents the distribution of the compound in the rat body using a simplified mathematical model.

Adopting a two-compartment open model, the equationbased calculation of half-lives for $\mathrm{HxCN}$ were about $6 \mathrm{~h}$ for phase I, known as the distribution phase that indicates rapid and effective absorption from the peritoneal cavity, and $350 \mathrm{~h}$ for phase II, known as the excretion phase that suggests a possible body accumulation after repeated exposure. To assess the efficacy of $\mathrm{HxCN}$ absorption from the alimentary tract on the basis of its excretion in faeces (main excretion route) and retention in the body, the administration routes, p.o. and i.p., were compared. The comparison showed that $120 \mathrm{~h}$ after p.o. administration, the total excretion of the compound in faeces accounted for about $52 \%$, of which $34 \%$ was excreted after first 24 h; most likely this was the non-absorbed pool.

Owing to the fact that $24 \mathrm{~h}$ after p.o. administration $53 \%$ of the received dose were retained in the body and the total balance of $\mathrm{HxCN}$, including the excreted quantity, was about $88 \%$, it may be assumed that absorption from the alimentary tract was about $60-70 \%$. This assumption seems to be confirmed by the outcome of the excretion balance after i.p. administration when total excretion with faeces was only $34 \%$ of the received dose after five days, while at the same time point $\mathrm{HxCN}$ retention in the body was only insignificantly higher (by about $12 \%$ ) than that after p.o. administration (about $58 \%$ of the dose).

Our experiment also demonstrated that, regardless of the route of $\left[{ }^{14} \mathrm{C}\right]-\mathrm{HxCN}$ administration, the highest concentrations, expressed as $\mathrm{kBq} / \mathrm{g}$ tissue, were found first in liver and then in adipose tissue, while the concentration in liver was several-fold higher than that in adipose tissue. For example, the concentration ratio for liver/adipose tissue $24 \mathrm{~h}$ after p.o. administration of $\mathrm{HxCN}$ was 6.22 and was comparable with that determined by Asplund et al. [30]. They administered rats with single oral dose of hexachloronaphthalene isomers mixture (mainly 1,2,3,5,6,7and 1,2,3,4,6,7-hexachloronaphthalene) and examined the retention in liver and adipose tissue. The $\mathrm{L} / \mathrm{A}$ ratio determined by those authors was found to be remarkably high: 7.3 after $24 \mathrm{~h}$ and 1.1 after ten days [30].

Our study showed that $24 \mathrm{~h}$ after $\mathrm{HxCN}$ administration the retention in liver was highest (about 32\% after p.o and $38 \%$ after i.p. administration). These results are in agreement with those obtained by Asplund et al. [30] who also observed the highest $\mathrm{HxCN}$ concentration in liver (about $35 \%$ of the administered dose) $24 \mathrm{~h}$ after its administration. Such a strong affinity to liver for tetra- and pentachlonaphthalene was not observed in our earlier experiment, in which the liver retention after a single dose of both compounds given to rats hardly reached several percent [48].

The present study also revealed that, while $\mathrm{HxCN}$ concentration in liver was significantly reduced five days after administration and the retention in this organ, regardless of the administration route, was comparable (16\% after p.o. and $18 \%$ after i.p. administration), in adipose tissue the opposite effect was observed; after p.o. administration $\mathrm{HxCN}$ concentration gradually increased in adipose tissue, reaching the maximum level at the final time point (five days after administration). The observed retention in this tissue (about $26 \%$ of the received dose after five days) was comparable with that found in the experiment 
performed by Asplund et al. [30]. However, they revealed that the level of $\mathrm{HxCN}$ concentration in adipose tissue reached the maximum value (about 35\%) ten days after administration of the compound.

Constant increase in $\mathrm{HxCN}$ concentrations (regardless of administration route) was also observed in other organs (brain, sciatic nerve and adrenals), but due to their low absolute mass (mainly that of adrenals) they did not play a role in the total body balance. Nevertheless, it should be noted that $\mathrm{HxCN}$ concentrations in these organs in terms of w/w ratio were comparable with (or even higher than) those observed in kidneys or spleen. Therefore, the conjecture that not only liver but also the nervous system and adrenals may appear to be critical organs for $\mathrm{HxCN}$ cannot be ruled out.

In conclusion, hexachloronaphthalene has a slow turnover rate in the rat and, especially in the case of repeated exposure, may accumulate in the body, forming long-term storage compartments.

\section{REFERENCES}

1. IPCS (International Programme on Chemical Safety). Concise International Chemical Assessment Document (CICAD) No. 34. Chlorinated Naphthalenes. Geneva: World Health Organization (WHO); 2001.

2. Yamashita N, Kannan K, Imagawa T, Miyazaki A, Giesy JP. Concentrations and profiles of polychlorinated naphthalene congeners in eighteen technical polychlorinated biphenyl preparations. Environ Sci Technol 2000;34:4236-41.

3. Falandysz J. Polychlorinated naphthalenes: an environmental update. Environ Pollut 1998;101:77-90.

4. Schiavone A, Kannan K, Horii Y, Focardi S, Corsolini S. Polybrominated diphenyl ethers, polychlorinated naphthalenes and polycyclic musks in human fat from Italy: comparison to polychlorinated biphenyls and organochlorine pesticides. Environ Pollut 2010;158(2):599-606. DOI 10.1016/j.envpol.2009.08.011.
5. Bidleman TF, Helm PA, Braune BM, Gabrielsen GW. Polychlorinated naphthalenes in polar environments - a review. Sci Total Environ 2010;408(15):2919-35. DOI 10.1016/j.scitotenv.2009.09.013.

6. Martí-Cid R, Llobet JM, Castell V, Domingo JL. Human exposure to polychlorinated naphthalenes and polychlorinated diphenyl ethers from foods in Catalonia, Spain: temporal trend. Environ Sci Technol 2008;42(11):4195-201.

7. Lee SC, Harner T, Pozo K, Shoeib M, Wania F, Muir DC, et al. Polychlorinated naphthalenes in the Global Atmospheric Passive sampling (GAPS) study. Environ Sci Technol 2007;41(8):2680-7.

8. Rose M, Falandysz J. Emerging POPs. A special session at "Dioxin 2008" in Birmingham. Rocz Panstw Zakl Hig 2008;59(4):473-81, 483-92 [in English and Polish].

9. Orlikowska A, Hanari N, Wyrzykowska B, Bochentin I, Horii Y, Yamashita N, et al. Airborne chloronaphthalenes in Scots pine needles of Poland. Chemosphere 2009;75(9): 1196-205. DOI 10.1016/j.chemosphere.2009.02.024.

10. Hayward D. Identification of bioaccumulating polychlorinated naphthalenes and their toxicological significance. Environ Res 1998;76:1-18.

11. Helm PA, Bidleman TF. Current combustion-related sources contribute to polychlorinated naphthalene and dioxin-like polychlorinated biphenyl levels and profiles in air in Toronto, Canada. Environ Sci Technol 2003;37(6):1075-82.

12. Falandysz J. Chloronaphthalenes as food-chain contaminants: a review. Food Addit Contam 2003;20(11):995-1014.

13. Harner TF, Lee RGM, Jones KC. Polychlorinated naphthalenes in the atmosphere. In: Lipnick RL, editor. Persistent, Bioaccumulative and Toxic Chemicals II: Assessment and New Chemicals. Washington: American Chemical Society; 2001. p. 223-34.

14. Hanari N, Kannan K, Horii Y, Taniyasu S, Yamashita N, Jude DJ, et al. Polychlorinated naphthalenes and polychlorinated biphenyls in benthic organisms of a Great Lakes food chain. Arch Environ Contam Toxicol 2004;47:84-93. DOI 10.1007/s00244-003-3106-6. 
15. Corsolini S, Kannan K, Imagawa T, Focardi S, Giesy J. Polychloronaphthalenes and other dioxin-like compounds in Arctic and Antarctic marine food webs. Environ Sci Technol 2002;36(16):3490-6.

16. Helm PA, Gewurtz SB, Whittle DM, Marvin CH, Fisk AT, Tomy GT. Occurrence and biomagnification of polychlorinated naphthalenes and non- and mono-ortho PCBs in Lake Ontario sediment and biota. Environ Sci Technol 2008;42(4):1024-31.

17. Kannan K, Yamashita N, Imagawa T, Decoen W, Khim JS, Day RM, et al. Polychlorinated naphthalenes and polychlorinated biphenyls in fishes from Michigan waters including the Great Lakes. Environ Sci Technol 2000;34:566-72.

18. Van de Plassche EJ, Schwegler AMGR. Polychlorinated Naphthalenes. Dossier prepared for the third meeting of the UN-ECE Ad hoc Expert Group on POPs. Royal Haskoning report L0002.A0/R0010/EVDP/TL; 2002.

19. Lundgren K, Tysklind M, Ishaq R, Broman D, van Bavel B. Polychlorinated naphthalene levels, distribution, and biomagnification in a benthic food chain in the Baltic Sea. Environ Sci Technol 2002;36(23):5005-13.

20. Domingo JL. Polychlorinated naphthalenes (PCNs) in aquatic species and human exposure through the diet: A review. J Chromatogr A 2004;1054:325-32.

21. Llobet JM, Falco G, Bocio A, Domingo JL. Human exposure to polychlorinated naphthalenes through the consumption of edible marine species. Chemosphere 2007;66:1107-13. DOI 10.1016/j.chemosphere.2006.06.058.

22. Fernandes A, Mortimer D, Gem M, Smith F, Rose M, Panton $\mathrm{S}$, et al. Polychlorinated naphthalenes (PCNs): congener specific analysis, occurrence in food, and dietary exposure in the UK. Environ Sci Technol 2010;44(9):533-8. DOI 10.1021/ es $903502 \mathrm{~g}$.

23. Fernandes A, Tlustos C, Rose M, Smith F, Carr M, Panton S. Polychlorinatednaphthalenes (PCNs) in Irish foods: Occurrence and human dietary exposure. Chemosphere 2011;85(3):3228. DOI 10.1016/j.chemosphere.2011.06.093.
24. Weistrand C, Noren K. Polychlorinated naphthalenes and other organochlorine contaminants in human adipose tissue and liver. J Toxicol Environ Health A 1998;53:293-311.

25. Kunisue T, Johnson-Restrepo B, Hilker DR, Aldous KM, Kannan K. Polychlorinated naphthalenes in human adipose tissue from New York, USA. Environ Pollut 2009;157(3): 910-5.

26. Lunden A, Noren K. Polychlorinated naphthalenes and other organochlorine contaminants in Swedish human milk 19721992. Arch Environ Contam Toxicol 1998;34(4):414-23.

27. Blankenship AL, Kannan K, Villalobos SA, Villeneuve DL, Falandysz J, Imagawa T, et al. Relative potencies of individual polychlorinated naphthalenes and Halowax mixtures to induce Ah receptor-mediated responses. Environ Sci Technol 2000;34:3153-8.

28. Villeneuve DL, Kannan K, Khim JS, Falandysz, J, Nikiforov VA, Blankenship AL, et al. Relative potencies of individual polychlorinated naphthalenes to induce dioxin-like responses in fish and mammalian in vitro bioassays. Arch Environ Contam Toxicol 2000;39:273-81. DOI 10.1007/s002440010105.

29. Kilanowicz A, Skrzypinska-Gawrysiak M. Toxicity of hexachloronaphthalene $(\mathrm{HxCN})$ and induction of CYP $1 A$ in rats. Ecotoxicol Environ Saf 2010;73(2):196-205. DOI 10.1016/j. ecoenv.2009.08.018

30. Asplund L, Jakobsson E, Haglund P, Bergman A. 1,2,3,5,6,7-Hexachloronaphthalene selective retention in rat liver and appearance in wildlife. Chemosphere 1994;28: 2075-86.

31. Auger P, Maialyandi M, Wightman RH, Bensimon C, Williams DT. Improved syntheses and complete characterization of some polychloronaphthalenes. Environ Sci Technol 1993;27:1673-80.

32. Mahin DT, Lofberg RT. A simplified method of sample preparation for determination of tritium, carbon 14 or sulfur 35 in blood or tissue by liquid scintillation counting. Anal Biochem 1966;16:500-9.

33. Krzymowski T. Physiology of Animals. Warszawa: Państwowe Wydawnictwo Rolnicze i Leśne; 1973 [in Polish]. 
34. Matthews HB, Anderson MW. The distribution and excretion of 2,4,5,2',5'-pentachlorobiphenyl in the rat. Drug Metab Dispos 1975;3:211-9.

35. Birnbaum LS, Decad GM, Matthews HB. Disposition and excretion of 2,3,7,8-tetrachlorodibenzofuran in the rat. Toxicol Appl Pharmacol 1980;55:342-52.

36. Williams DT, Kennedy B, LeBel GL. Chlorinated naphthalenes in human adipose tissue from Ontario municipalities. Chemosphere 1993;27:795-806.

37. Haglund P, Jakobsson E, Masuda Y. Isomer-specific analysis of polychlorinated naphthalenes in Kanechlor KC 400, Yusho rice oil, and adipose tissue of a Yusho victim. Organohalogen Comp 1995;26:405-10.

38. Ryan JJ, Masuda Y. Polychlorinated naphthalenes (PCNs) in rice oil poisonings. Organohalogen Comp 1994;21:251-4.

39. Weistrand C, Noren K, Nilsson A. Occupational exposure. Organochlorine compounds in blood plasma from potentially exposed workers. PCB, PCN, PCDD/F, HCB and methylsulfonyl metabolites of PCB. Environ Sci Pollut Res Int 1997;4(1):2-9.

40. Hayward DG, Charles JM, Voss de Bettancourt C, Stephens DE, Papanek PJ, Lance LL, et al. PCDD and PCDF in breast milk as correlated with fish consumption in southern California. Chemosphere 1989;18:455-68.

41. Noren K, Meironeyte D. Certain organochlorine and organobromine contaminants in Swedish human milk: a perspective of past 20-30 years. Chemosphere 2000;40:1111-23.
42. Kilanowicz A, Skrzypinska-Gawrysiak M, Sapota A, Galoch A, Daragó A. Subacute toxicity of polychlorinated naphthalenes and their effect on cytochrome P-450. Ecotoxicol Environ Saf 2009;72:650-7. DOI 10.1016/j.ecoenv.2008.07.010.

43. Kilanowicz A, Sitarek K, Skrzypinska-Gawrysiak M, Sapota A. Prenatal developmental toxicity of polychlorinated naphthalenes (PCNs) in the rat. Ecotoxicol Environ Saf 2011;74(3):504-12. DOI 10.1016/j.ecoenv.2010.09.025.

44. Galoch A, Sapota A, Skrzypinska-Gawrysiak M, Kilanowicz A. Acute toxicity of polychlorinated naphthalenes and their effect on cytochrome P-450. Human Exp Toxicol 2006;25:85-92.

45. Omura M, Masuda Y, Hirata M, Tanaka A, Makita Y, Ogara R, et al. Onset of spermatogenesis is accelerated by gestational administration of 1,2,3,4,6,7-hexachlorinated naphthalene in male rat offspring. Environ Health Perspect 2000;108(6):539-44.

46. Jakobsson E, Nilsson A, Lund BO, Klasson-Wehler E. Distribution, elimination and irreversible binding of 14C-labelled PCN in the rat. In: Jakobsson E, editor. Synthesis and Analysis of Chlorinated Naphthalenes. Stockholm: University of Stockholm; 1994.

47. Klasson-Wehler E, Jakobsson E, Orn U. Metabolism of polychlorinated naphthalenes and tetrabrominated diphenyl ether. Organohalogen Comp 1996;28:495-9.

48. Kilanowicz A, Galoch A, Sapota A. Tissue distribution and elimination of selected chlorinated naphthalenes. Int J Occup Med Environ Health 2004;17(3):355-60.

This work is available in Open Access model and licensed under a Creative Commons Attribution-NonCommercial 3.0 Poland License - http://creativecommons.org/ licenses/by-nc/3.0/pl/deed.en. 